\title{
Ammonium citrate as enhancement for electrodialytic soil remediation and investigation of soil solution during the process
}

Dias-Ferreira, Celia; Kirkelund, Gunvor Marie; Ottosen, Lisbeth M.

Published in:

Chemosphere

Link to article, DOI:

10.1016/j.chemosphere.2014.08.064

Publication date:

2015

Document Version

Peer reviewed version

Link back to DTU Orbit

Citation (APA):

Dias-Ferreira, C., Kirkelund, G. M., \& Ottosen, L. M. (2015). Ammonium citrate as enhancement for electrodialytic soil remediation and investigation of soil solution during the process. Chemosphere, 119, 889-895. https://doi.org/10.1016/j.chemosphere.2014.08.064

\section{General rights}

Copyright and moral rights for the publications made accessible in the public portal are retained by the authors and/or other copyright owners and it is a condition of accessing publications that users recognise and abide by the legal requirements associated with these rights.

- Users may download and print one copy of any publication from the public portal for the purpose of private study or research.

- You may not further distribute the material or use it for any profit-making activity or commercial gain

- You may freely distribute the URL identifying the publication in the public portal 
This is an author produced version of a paper published in CHEMOSPHERE. This paper has been peer reviewed but does not include the final publisher proof corrections nor jornal pagination.

Citation for the published paper:

Celia Dias-Ferreira, Gunvor M. Kirkelund, Lisbeth M. Ottosen, "Ammonium citrate as enhancement for electrodialytic soil remediation and investigation of soil solution during the process"

Chemosphere, volume 119, 2015, Pages 889-895

http://dx.doi.org/10.1016/j.chemosphere.2014.08.064

Access to the published version may require jornal subscription. 


\title{
Ammonium citrate as enhancement for electrodialytic soil remediation and investigation of soil solution during the process \\ Celia Dias-Ferreira ${ }^{\mathrm{a}^{*}}$, Gunvor M. Kirkelund ${ }^{\mathrm{b}}$, Lisbeth M. Ottosen ${ }^{\mathrm{c}}$
}

\author{
${ }^{a}$ CERNAS - Research Center for Natural Resources, Environment and Society, Escola \\ Superior Agraria de Coimbra, Instituto Politecnico de Coimbra 3045-601 Coimbra, Portugal \\ celia@esac.pt \\ ${ }^{\mathrm{b}}$ Department of Civil Engineering, Technical University of Denmark, 2800 Lyngby, \\ Denmark gunki@,byg.dtu.dk \\ ${ }^{c}$ Department of Civil Engineering, Technical University of Denmark, 2800 Lyngby, \\ Denmark lo@,byg.dtu.dk \\ * Corresponding author tel: +351939303952
}

\begin{abstract}
Seven electrodialytic experiments were conducted using ammonium citrate as enhancing agent to remediate copper and chromium-contaminated soil from a wood-preservation site. The purpose was to investigate the effect of current density $\left(0.2,1.0\right.$ and $\left.1.5 \mathrm{~mA} . \mathrm{cm}^{-2}\right)$, concentration of enhancing agent $(0.25,0.5$ and $1.0 \mathrm{M})$ and remediation times $(21,42$ and 117 d) for the removal of $\mathrm{Cu}$ and $\mathrm{Cr}$ from a calcareous soil. To gain insight on metal behavior, soil solution was periodically collected using suction cups.

It was seen that current densities higher than $1.0 \mathrm{~mA} . \mathrm{cm}^{-2}$ did not increase removal and thus using too high current densities can be a waste of energy. Desorption rate is important and both remediation time and ammonium citrate concentration are relevant parameters.

It was possible to collect soil solution samples following an adaptation of the experimental set-up to ensure continuous supply of ammonium citrate to the soil in order to keep it saturated during the remediation. Monitoring soil solution gives valuable information on the evolution of remediation and helps deciding when the soil is remediated.

Final concentrations in the soil ranged from 220-360 mg Cu. $\mathrm{kg}^{-1}$ (removals: $78 \%-86 \%$ ) and 440-590 mg Cr. $\mathrm{kg}^{-1}$ (removals: 35-51\%), being within the $500 \mathrm{mg} \cdot \mathrm{kg}^{-1}$ limit for a clean soil only for $\mathrm{Cu}$. While further optimization is still required for $\mathrm{Cr}$, the removal percentages are the highest achieved so far, for a real $\mathrm{Cu}$ and $\mathrm{Cr}$-contaminated, calcareous soil. The results highlight EDR potential to remediate metal polluted soils at neutral to alkaline $\mathrm{pH}$ by choosing a good enhancement solution.
\end{abstract}

Keywords: copper; chromium; treated wood; suction cups; electrokinetic remediation; contaminated soil. 


\section{Introduction}

Removal of heavy metals from industrially polluted soils in an applied electric field (electrokinetic or electrodialytic remediation) can be very efficient with removal percentages of up to $99 \%$ (Ottosen et al., 2009). The remediation is based on electromigration, which is transport of ions in the applied DC field. The fraction of heavy metals in ionic form in the soil solution (electric double layer or bulk) will be transported towards the electrode of opposite polarity. As the process proceeds the heavy metals are depleted from the soil and concentrated around the electrodes.

Desorption processes are often the rate limiting step for the remediation when dealing with industrially polluted soils. Acidification of the soil from the anode causes the necessary desorption and thus mobilization of many of the heavy metals for electromigration. Some soils have though a high buffering capacity against acidification e.g. due to a high content of carbonates. Here the acidic front develops slowly and subsequently the remediation is time consuming. Enhancement solution can be added to the soil for aiding desorption of heavy metals at a neutral to alkaline $\mathrm{pH}$. Enhancement solutions can be used for changing the physicochemical conditions in the soil as $\mathrm{pH}$ and redox conditions, or for formation of charged complexes with the actual heavy metals. Examples of enhancement solutions are EDDS and EDTA for Pb (Alcántara et al., 2012; Suzuki et al., 2014), ammonia for $\mathrm{Cu}$ (Chen et al., 2011; Ottosen et al. 2000) and citric acid for Cr and Cd (Gent et al., 2004). Stepwise addition of EDTA, $\mathrm{NaOH}$, and sodium dithionite+sodium citrate enabled removal of $\mathrm{Cu}$ at neutral $\mathrm{pH}$ (Chang et al, 2010). In the case of on-site remediation the enhancement solution can be mixed into the soil prior to the remediation. For in-situ remediation the enhancement solution can be used as electrolyte solutions around the electrodes and transported into the soil by electromigration or electroosmosis.

The order of removal for different heavy metals by electromigration from industrially polluted soils under an acidic front has been reported in Jensen et al. (2012) and Cr was in every case the most difficult to remove. From this work, the review by Ottosen et al. (2009) and the works by Brosky and Pamukcu (2013) and Pamukcu et al (2004) it is seen that $\mathrm{Cr}$ and $\mathrm{Cu}$ are not easily removed from contaminated soils. $\mathrm{Cr}$ exists mainly as $\mathrm{Cr}(\mathrm{III})$ or $\mathrm{Cr}(\mathrm{VI})$ in soils dependent on the prevailing redox potential. $\mathrm{Cr}(\mathrm{VI})$ adsorption increases with decreasing $\mathrm{pH}$, whereas on the contrary $\mathrm{Cr}(\mathrm{III})$ desorption is most significant at low $\mathrm{pH}$. Whether the relatively poor $\mathrm{Cr}$ removal obtained is due to adsorption of $\mathrm{Cr}(\mathrm{VI})$ at low $\mathrm{pH}$ or because the $\mathrm{pH}$ reached was not low enough to desorb $\mathrm{Cr}$ (III) has not been investigated in details. An alternative to using enhancing solutions is using an externally applied electric current to promote the transformation of $\mathrm{Cr}$ and $\mathrm{Cu}$ into benign species, as shown in the works by Brosky and Pamukcu (2013) and Pamukcu et al (2004). A conclusion is though that $\mathrm{Cr}$ is difficult to remove without enhancement.

The present work tests ammonium citrate (Am-Cit) as enhancement solution for the simultaneous removal of $\mathrm{Cr}$ and $\mathrm{Cu}$ by electrodialytic remediation (EDR). Am-Cit has been 
tested as enhancement for a wide range of polluted materials (Chen et al., 2011; Ferreira et al., 2002; Nystroem et al., 2006; Ottosen et al., 2005a). For remediation of a calcareous soil polluted with $\mathrm{Cu}$ and $\mathrm{Cr}$, Am-Cit seems a good option, because carbonates will stay immobilized at a high $\mathrm{pH}$ and therefore energy will not be wasted in transporting $\mathrm{Ca}^{2+}$ out of the soil, as when the carbonates are dissolved by the acidic front (Nystroem et al., 2006). In addition, Am-Cit will form tetraammine-complexes and other complexes with $\mathrm{Cu}^{2+}$ and $\mathrm{Cr}^{3+}$ (Martell, 1977; Pedersen, 2002).

In the present work a method for soil solution sampling is developed to increased knowledge on both desorption and electromigration during EDR. While sampling soil solution gives valuable information on the behavior of heavy metals, there are only few studies where soil solution was monitored (mostly by using suction cups), and these were carried out without ion-exchange membranes (Li et al., 2010; Fan et al., 2014; Buchireddy et al., 2009). These works do not discuss possible interferences caused by sampling. In EDR, soil sampling has been hindered because of undersaturation of the soil, and extracting soil solution was found almost impossible (Ribeiro, 1998). The most widely used non-destructive sampling system for field applications are suction cups and this method is used in this work, together with EDR.

The traditional EDR laboratory cell (Figure 1-a) consists of anode (+1), soil, and cathode (-1) compartments. The ions in the soil move towards the electrode of opposite charge, cross the ion-exchange membranes, and concentrate in the electrolytes (Ottosen et al., (Ottosen et al., 1997). EDR has been tested for several types of contaminated waste (harbor sediments, fly ash, soil and mine tailings) at laboratory scale (Ferreira et al., 2008; Hansen et al., 2007; Kirkelund et al., 2009; Ottosen et al., 2012) and MSWI-APC residues in continuous benchscale (Jensen et al., 2010) and pilot-scale (Kirkelund et al., 2010).

The major aims of the present work are (I) to develop a method which enables sampling of soil solution during EDR experiments, (II) investigate how ammonium citrate influences the remediation of both $\mathrm{Cu}$ and $\mathrm{Cr}$ in a calcareous soil and (III) analyze how $\mathrm{Cu}$ and $\mathrm{Cr}$ behave in soil solution during EDR.

\section{Materials and methods}

\subsection{Soil and analytical techniques}

Soils were sampled from a Danish site which formerly housed a wood preservation facility (1961-1981) using Boliden K33 as preservative. Samples of topsoil were taken at two different locations at the site (soil 1 and 2). The samples were air-dried and sieved (4 mm). Heavy metals were determined according to Danish Standard DS259: $1.0 \mathrm{~g}$ dry soil and 20.0 $\mathrm{mL}$ half-concentrated $\mathrm{HNO}_{3}$ were heated at $200 \mathrm{kPa}\left(120^{\circ} \mathrm{C}\right)$ for 30 minutes using an autoclave. The suspension was filtered by vacuum $(0.45 \mu \mathrm{m})$. Heavy metal concentrations were measured in the filtrate by AAS, and expressed as $\mathrm{mg} \mathrm{kg}^{-1}$ dry material. The $\mathrm{pH}$ was measured in $1 \mathrm{M} \mathrm{KCl}$ at a liquid-to-solid (L:S) ratio of 2.5, after $1 \mathrm{~h}$ of agitation using a Radiometer electrode. Carbonates were determined by the Sheibler method (Loeppert and Suarez, 1995) and grain size by a combined sieve and pipette method. 
(a)

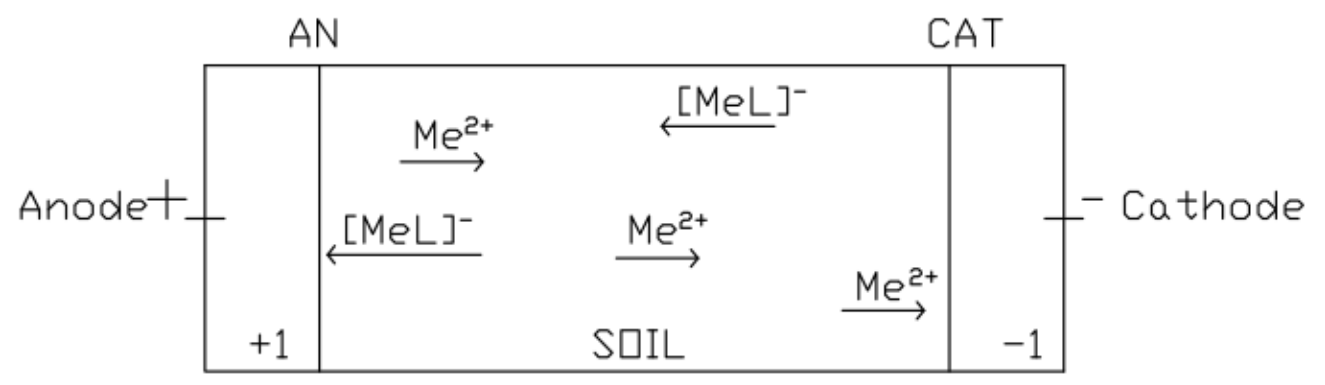

(b)

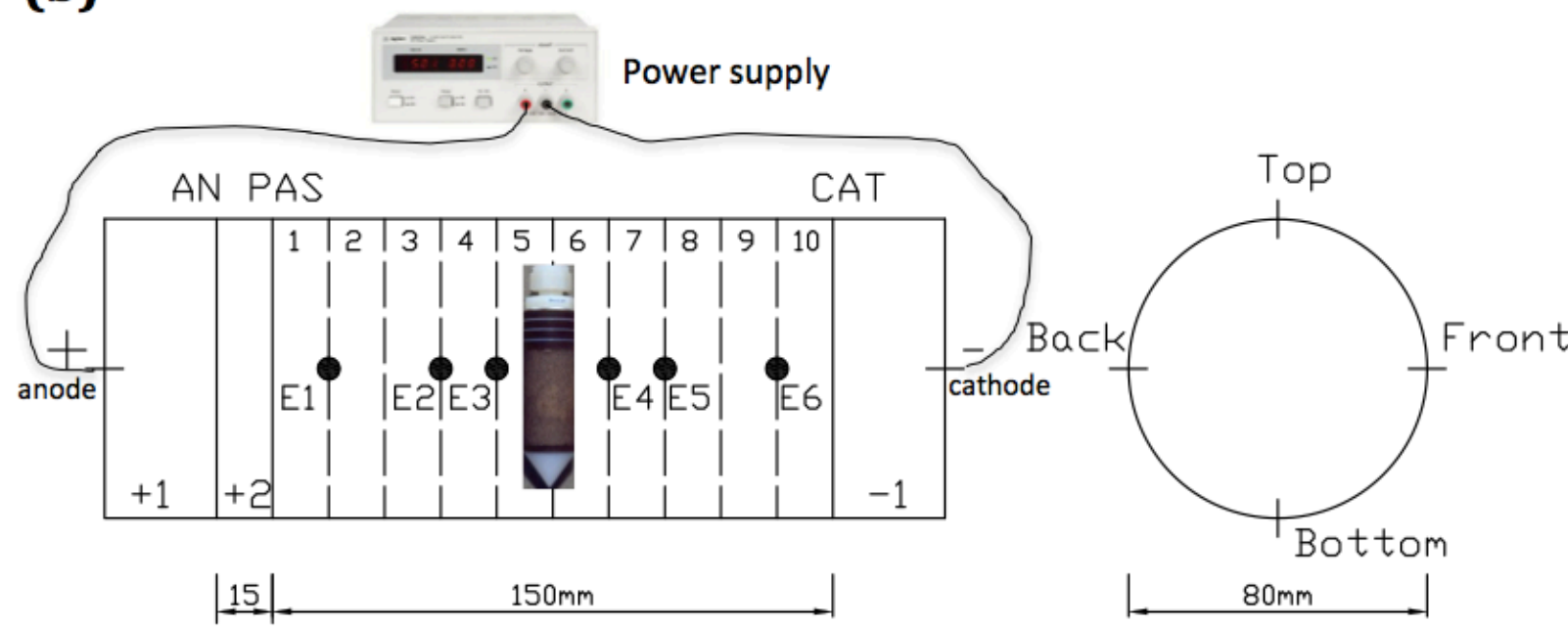

Figure 1: Laboratory cell used for electrodialytic remediation (a) original; (b) modified set-up enabling soil sampling during experiments. The soil is placed in the central compartment, which at the end of the experiment is divided into 10 slices (numbered 1 to 10). The suction cup is placed between slice 5 and 6. In experiment 4 at each position (E1, E2, E3, E4, E5 and E6) 4 reference electrodes are placed (at the top, front, bottom and back of the cell), as shown on the projection on right side. (CAT - cation-exchange membrane; AN - anion-exchange membrane; PAS - passive membrane; $\mathrm{Me}^{2+}$ - di-valent metal ion; $[\mathrm{MeL}]^{-}$- metal complex; - - reference electrode, only in experiment 4).

The soil characterization is shown in Table 1. According to Danish regulations (Miljøministeriet, 2010) both soils are classified as polluted since $\mathrm{Cu}$ and $\mathrm{Cr}$ exceed the limiting value $500 \mathrm{mg} \mathrm{kg}^{-1}$. The soil $\mathrm{pH}$ is neutral to alkaline. Under these conditions $\mathrm{Cu}$ is likely precipitated, as is evident from the Eh-pH stability diagrams in Bhattacharya (2002) or 
adsorbed to the soil particles. The wood preservative used at the site contained chromate $\left(\mathrm{CrO}^{2-}\right)$. However, $\mathrm{Cr}(\mathrm{VI})$ can easily be reduced in soil by e.g. iron oxides (Landrot et al. 2012). The actual pollution is old so the prevailing form of $\mathrm{Cr}$ is expected to be $\mathrm{Cr}$ (III), since $\mathrm{Cr}(\mathrm{VI})$ is relatively mobile and would most likely have been washed out. Ottosen et al. (2009) showed that $\mathrm{Cr}$ is strongly adsorbed in the present soil (Soil 2, in (Ottosen et al 2009)).

Table 1. Characterization of soil samples from a wood preservation site

\begin{tabular}{lll}
\hline & Soil 1 & Soil 2 \\
\hline $\mathrm{Cu}(\mathrm{mg} / \mathrm{kg})$ & $4710 \pm 1980$ & $1630 \pm 80$ \\
\hline $\mathrm{Cr}(\mathrm{mg} / \mathrm{kg})$ & $1520 \pm 530$ & $920 \pm 50$ \\
\hline Regulation limit $\mathrm{Cu}$ and $\mathrm{Cr}(\mathrm{mg} / \mathrm{kg})($ Miljøministeriet, $(2010)$ & 500 & 500 \\
\hline Carbonate content $($ Sheibler method) $(\%)$ & 3.2 & 2.7 \\
\hline Organic content $\left(\right.$ loss on ignition at $\left.550^{\circ} \mathrm{C}\right)(\%)$ & 3.2 & 2.1 \\
\hline Clay $(<0.002 \mathrm{~mm})(\%)$ & 3.6 & 1.8 \\
\hline Silt $(0.002-0.06 \mathrm{~mm})(\%)$ & 19.2 & 18.7 \\
\hline Sand $(0.06-2 \mathrm{~mm})(\%)$ & 61.2 & 59.0 \\
\hline $\mathrm{pH}$ & 7.8 & 7.0 \\
\hline
\end{tabular}

\subsection{Remediation experiments}

EDR experiments were made in a glass laboratory cell (Figure 1-b). The cell is modified compared to the original set-up and consists of: two electrolyte compartments $(+1)$ and $(-1)$, the soil (1-10); and a concentration compartment $(+2)$. Compartment $(+2)$ allows continuous addition of Am-Cit to the soil and prevents it from drying. Ion-exchange membranes (anionexchange membrane: AR-204-SZRA-7639 and cation-exchange membrane CR67-HMR166A, from Ionics) and a passive membrane (1-layer cotton cloth and 1-layer filter paper) separate these compartments as shown. Platinum coated titanium electrodes (from Bergsøe, Anti Corrosion) were used as working electrodes and silver was used for reference electrodes. In the electrolyte compartments $0.25 \mathrm{M}$ Am-Cit $\mathrm{pH} 8$ (adjusted with $\mathrm{NaOH}$ ) was circulated between the compartment and Erlenmeyer flasks (using Pan World Magnet Pump, Model NH $-5 \mathrm{PX})$. The initial volumes were $1.0 \mathrm{~L}$ for the anolyte and $1.0 \mathrm{~L}$ for the catholyte. $0,5 \mathrm{~L}$ of Am-Cit pH8 was circulated between compartment (+2) and an Erlenmeyer flask. Air-dried soil was mixed with Am-Cit (same concentration as in +2 ) to a total water content of $11-15 \%$.

Seven EDR experiments were conducted (table 2) to investigate which concentration of AmCit was most efficient in enhancing remediation (exp.1-3) and how different current densities and time would affect the remediation (exp.4-7). Current densities were kept constant (Hewlett Packard E3612A). Voltage and pH were measured every weekday. The anolyte's pH was maintained over 8 by adding $\mathrm{NaOH}$, when required.

At the end of the experiments, membranes were soaked in $1 \mathrm{M} \mathrm{HNO}_{3}$ and electrodes were rinsed in $5 \mathrm{M} \mathrm{HNO}_{3}$ to extract metals. The soil was segmented into 10 slices $(1.5 \mathrm{~cm})$, from 
anode to cathode. $\mathrm{Cu}$ and $\mathrm{Cr}$ concentrations and $\mathrm{pH}$ were measured in duplicate in all solutions and soil slices.

Table 2. EDR experiments conducted with polluted soil

\begin{tabular}{cccccc}
\hline Experiment & Soil & $\begin{array}{c}\text { Current } \\
(\mathbf{m A})\end{array}$ & $\begin{array}{c}\text { Current } \\
\text { density } \\
\left(\mathbf{m A} / \mathbf{c m}^{\mathbf{2}}\right)\end{array}$ & $\begin{array}{c}\text { Duration } \\
(\mathbf{d a y s})\end{array}$ & $\begin{array}{c}\text { Ammonium citrate } \\
\text { concentration (M) }\end{array}$ \\
\hline 1 & 1 & 10 & 0.2 & 21 & 0.25 \\
\hline 2 & 1 & 10 & 0.2 & 21 & 0.50 \\
\hline 3 & 1 & 10 & 0.2 & 21 & 1.0 \\
\hline 4 & 2 & 50 & 1.0 & 21 & 1.0 \\
\hline 5 & 2 & 50 & 1.0 & 42 & 1.0 \\
\hline 6 & 2 & 75 & 1.5 & 42 & 1.0 \\
\hline 7 & 2 & 50 & 1.0 & 117 & \\
\hline
\end{tabular}

\subsection{Soil solution sampling}

A Prenart super quartz mini Teflon/quartz suction cup with a pore size of $2 \mu \mathrm{m}$ was used for soil solution sampling. This cup is small enough (length $=6.5 \mathrm{~cm}$; diameter $=1.2 \mathrm{~cm}$ ) to fit the EDR cell and is chemically inert. Before use, the cup was pre-treated by placing it in a thin slurry of soil and water and applying suction for $10 \mathrm{~min}$. This procedure fills the biggest pores of the cup, to ensure a tight capillary contact with the soil and avoid the strong sorption effect in new cups (Grossmann and Udluft, 1991).

During EDR the cup was placed in the middle of the soil compartment. Sampling was carried out using a $20-\mathrm{mL}$ plastic syringe, attached to the tube from the cup, by pulling back the plunger to create vacuum. After collection (2-3 mL), both cup and tube were emptied and the cup was left without vacuum to avoid contamination of the next sample. Samples were taken at the beginning of experiments and three times a week. For experiment 7 sampling started after $42 \mathrm{~d}$.

In experiment 4 four reference electrodes were placed in each of 6 slices (Figure 1-b). The potential drop between reference and working electrodes was measured before and after sampling to evaluate the influence of the suction cup on the electric field distribution.

\section{Results and discussion}

The recoveries (total amount of metal found in the soil and in all collected solutions after the experiment ended divided by the total amount of heavy metal in the soil before the experiment) for $\mathrm{Cu}$ were between $90-120 \%$ and for $\mathrm{Cr}$ between $88-115 \%$ (table 3 ), which is considered acceptable as industrially polluted soils have non-homogeneous distribution of pollutants. 
Table 3. Recovery values for copper and chromium in EDR experiments 1 to 7

\begin{tabular}{|l|c|c|}
\hline Experiment & \multicolumn{2}{|c|}{ Recoveries (\%) } \\
\hline & $\mathbf{C u}$ & $\mathbf{C r}$ \\
\hline 1 & 120,3 & 91,7 \\
\hline 2 & 96,1 & 88,5 \\
\hline 3 & 98,1 & 114,6 \\
\hline 4 & 107,4 & 101,2 \\
\hline 5 & 108,7 & 104,3 \\
\hline 6 & 118,9 & 104,6 \\
\hline 7 & 90,3 & 96,0 \\
\hline
\end{tabular}

\subsection{Removal of $\mathrm{Cu}$ and $\mathrm{Cr}$ from soil to electrolytes.}

The removals (amount in electrolytes, membranes and electrodes at the end of an experiment divided by the total amount in soil, soil solutions, membranes, electrodes and electrolytes) obtained using EDR are shown in Table 4. $\mathrm{Cu}$ and $\mathrm{Cr}$ are mainly removed to the anolyte, although $\mathrm{Cu}$ is also removed to the catholyte. This shows that $\mathrm{Cu}$ forms both positively and negatively charged complexes. $\mathrm{Cr}$ is mainly removed as negatively-charged complexes and hardly any $\mathrm{Cr}$ is found in the catholyte (corresponding to the finding of Pedersen (2002)) where Am-cit was used in combination with EDR of fly ash. Citric acid is used as reductant for $\mathrm{Cr}$ (VI), subsequently forming $\mathrm{Cr}$ (III)-cit complexes during the reduction process ( $\mathrm{Li} \&$ Deng 2007) and thus in case Cr(VI) was present, reduction likely occurred when adding Amcit and it is anticipated that negative $\mathrm{Cr}$ (III)-cit complexes were the major species removed.

Table 4. Overall removal of copper and chromium and distribution between cathode and anode of removed fraction (The removal is defined as total amount of metal in electrolytes, membranes and electrodes after experiment divided by the total amount of metal found after the experiment. The removal can be either to the cathode or the anode side of the cell and the percentages for this are based on the removal as $100 \%$ )

\begin{tabular}{|l|c|c|c|c|c|c|}
\hline Experiment & \multicolumn{2}{|c|}{ Metal Removal (\%) } & \multicolumn{2}{c|}{$\begin{array}{c}\text { To cathode (\% of } \\
\text { metal removed) }\end{array}$} & \multicolumn{2}{c|}{$\begin{array}{c}\text { To anode (\% of } \\
\text { metal removed) }\end{array}$} \\
\hline & $\mathrm{Cu}$ & $\mathrm{Cr}$ & $\mathrm{Cu}$ & $\mathrm{Cr}$ & $\mathrm{Cu}$ & $\mathrm{Cr}$ \\
\hline 1 & 4 & 3 & 45 & 10 & 55 & 90 \\
\hline 2 & 12 & 3 & 10 & 2 & 90 & 98 \\
\hline 3 & 11 & 6 & 20 & 5 & 80 & 95 \\
\hline 4 & 28 & 7 & 20 & 5 & 80 & 95 \\
\hline 5 & 32 & 14 & 30 & 1 & 70 & 99 \\
\hline 6 & 32 & 10 & 40 & 0 & 60 & 100 \\
\hline 7 & 78 & 35 & 47 & 2 & 53 & 98 \\
\hline
\end{tabular}


Experiments 1-3 were made to evaluate the influence of Am-cit concentration for enhancement of the remediation. With $0.25 \mathrm{M}$ (exp.1) $\mathrm{Cu}$ removal was approximately one third of when $0.50 \mathrm{M}$ was used (exp.2). Increasing concentration from $0.5 \mathrm{M}$ to $1.0 \mathrm{M}$ does not increase $\mathrm{Cu}$ removal. For $\mathrm{Cr}$ removals were similar for the two lowest concentrations, and doubled at 1.0 M (Table 4). The Cr removal was though still low (6\%) at this concentration. The remaining experiments were conducted with 1.0 M Am-Cit.

In experiments 4-7 the effect of current density and duration were investigated. Increasing from 1.0 to $1.5 \mathrm{~mA} \mathrm{~cm}^{-2}$ did not increase removals (experiments 5 versus 6 , table 4) showing that the limiting factor may the fraction of $\mathrm{Cu}$ and $\mathrm{Cr}$ mobile for electromigration and this is supported by the concentration in the soil solution decreases by increasing current density (exp. 3, 5, 6). Longer duration when applying $1.0 \mathrm{~mA} \mathrm{~cm}$ on the other hand gave higher removals. The removals increased in the order $21 \mathrm{~d}$ (exp.4) $<42 \mathrm{~d}(\exp .5)<117 \mathrm{~d}(\exp .7)$. That increased removals are obtained by increasing duration but not current density underlines that desorption rate is important. Either the reaction rate between ammonia citrate and the heavy metals is limiting the mobilization or the supply of Am-Cit into the soil.

\subsection{Heavy metal profiles in the soil and in soil solution}

Figure 2 shows $\mathrm{Cu}$ and $\mathrm{Cr}$ concentrations in the soil at the end (normalized with initial concentrations). In experiments 1-4 (21 d) Cu-profile shows a peak in the central part of the soil and lower concentrations closest to the electrodes. In the anode end of the soil the negatively charged $\mathrm{Cu}$ complexes electromigrate towards the anolyte, while positively charged copper electromigrates into adjacent soil slices, towards the cathode. The opposite happens on the cathode side, thus creating a peak in the middle. As remediation proceeds (exp. 5-6, 42 d), the peak reduces due to the continuous removal of copper from the soil, and for longer remediation times (exp.7, $117 \mathrm{~d}$ ) the profile becomes flat.

A Cr-peak is also seen in experiments 1-2, but for experiments 5-6 the shape changes, showing an accumulation ion the soil nearest to the cathode. Even though $\mathrm{Cr}$ is mainly removed to the anode side in these experiments (table 4), the concentration profiles clearly show that transport towards the cathode also takes place. Migration of $\mathrm{Cr}$ (III) towards the cathode has also been found in previous works (Buchireddy et al., 2009; Reddy and Chintamreddy, 2004) in parallel with decreasing $\mathrm{pH}$. In our experiments the original soil $\mathrm{pH}$ is 7-7.8, and final values are 8-9, so no acidification occurs. The Cr-peak on the cathode side disappears after $117 \mathrm{~d}$ (exp.7), indicating removal from soil.

Initial concentrations of Am-Cit are lower in experiments 1-2, and desorption equilibrium had not been reached when the experiments started. Soil solution concentrations of $\mathrm{Cu}$ and $\mathrm{Cr}$ (Figure 2) are lower in the beginning and increase with time. For 1.0 M Am-Cit (exp.3-6), Cu desorbs right from the start while $\mathrm{Cr}$ desorption takes longer. 

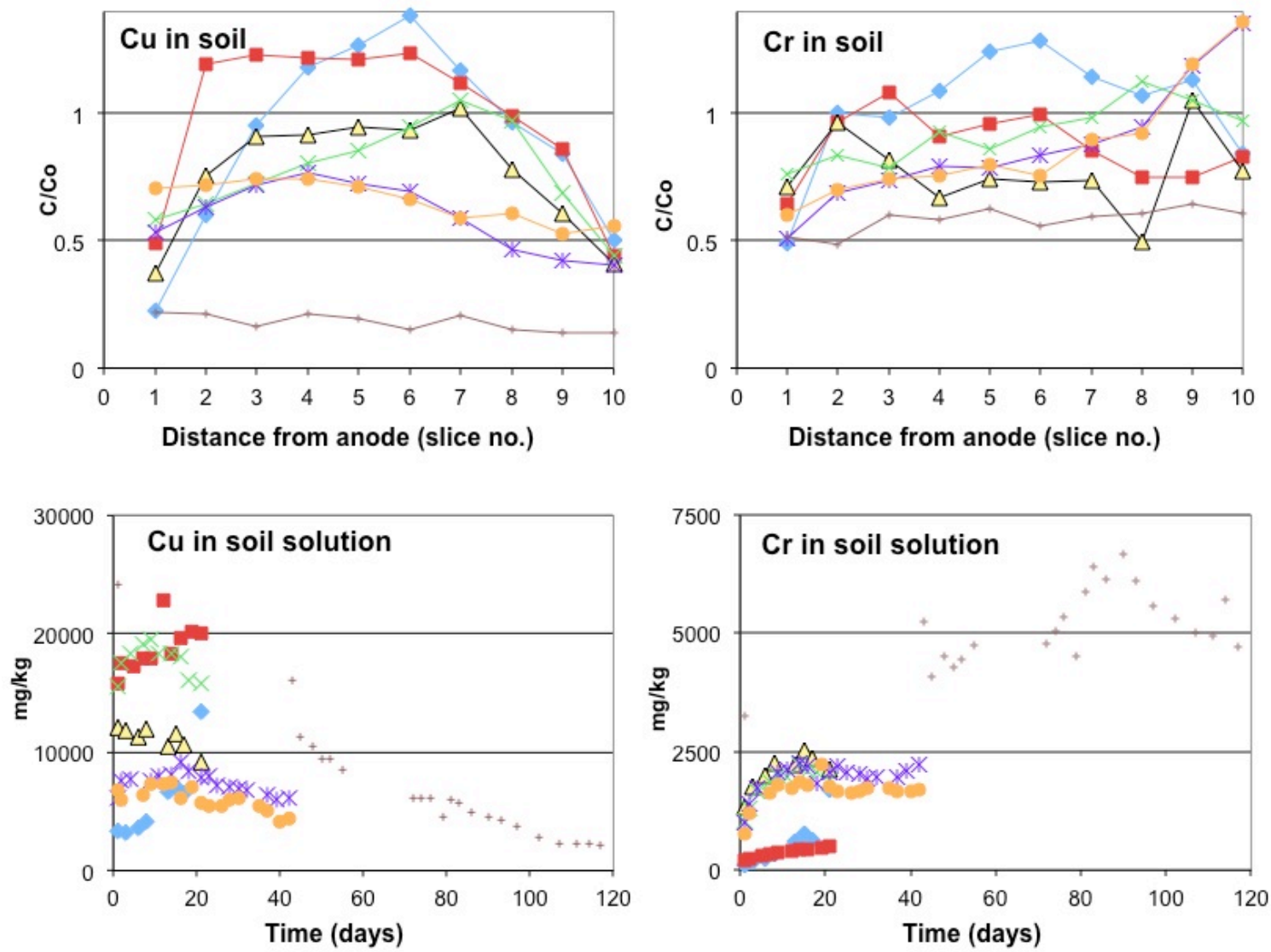

$\rightarrow$ Exp.1 $\rightarrow$ Exp.2 $\triangle$ Exp. $3 \rightarrow$ Exp. 4 *Exp. $5 \rightarrow$ Exp. $6 \rightarrow$ Exp. 7

Figure 2: Copper and chromium profiles in soil at the end of EDR experiments and evolution in soil solution.

The soil solution concentrations of $\mathrm{Cu}$ and $\mathrm{Cr}$ are high throughout the experiments, while decreasing in the soil (exp. 3-6). As $\mathrm{Cu}$ and $\mathrm{Cr}$ are continuously depleted in soil solution due to transport into the electrolytes, more is dissolved from the soil to re-establish equilibrium. Only when copper is no longer available for desorption do the soil solution concentrations decrease (exp. 7). Clearly, for Cr this point is not reached, as concentrations are still high after $117 \mathrm{~d}$, even though soil concentrations have been reduced with almost 50\%. The high concentration of $\mathrm{Cr}$ in the soil solution in experiment 7 may be due to $\mathrm{Cr}$ being present in uncharged species and thus not mobile for electromigration. As the $\mathrm{Cr}$ is desorbed, e.g. changing $\mathrm{pH}$ in the soil may cause charged species dependent on the actual speciation.

In experiment 7 , the final concentrations in the soil ranged from $220-360 \mathrm{mg} \mathrm{Cu} \mathrm{kg}{ }^{-1}$ (removals: $78 \%-86 \%$ ) and 440-590 $\mathrm{mg} \mathrm{Cr} \mathrm{kg}^{-1}$ (removals: $35-51 \%$ ). Cu levels are within the $500 \mathrm{mg} \mathrm{kg}^{-1}$ limit for a clean soil according to Danish regulations, but $\mathrm{Cr}$ remains slightly above this limit. Removals are nevertheless the highest reported in the literature so far, for a real $\mathrm{Cu}$ and $\mathrm{Cr}$-contaminated calcareous soil (Ottosen et al., 2005b). Buchireddy et al. (2009) and (Reddy and Chintamreddy, 2004) report higher Cr-removals (72\% and 46-82\%, respectively) with an artificially spiked soil, but these cannot be compared with our results, 
where contamination dates back to the 1960's (Ottosen et al. 2006). These results are encouraging and highlight the potential of EDR to remediate soils which are contaminated with a mixture of heavy metals at a neutral $\mathrm{pH}$ by choosing a good enhancement solution.

\subsection{Considerations on soil solution sampling and its interference on remediation}

Initial and final soil humidity was $12 \%-15 \%$ and $10-18 \%$ respectively. In addition, the humidity in the slice where the cup was placed did not vary much from other slices, meaning that the liquid compartment was working as intended to keep the soil saturated enabling soil solution sampling.

Placing a foreign object, such as the suction cup in the soil during EDR will influence the electric field distribution. In Ottosen et al. (2002) different pieces of construction refuse (stone, porous concrete and brick, and metallic screw) were placed in the soil during EDR and they all influenced the remediation. Thus it is expected that the suction cup will do so, too.

Figure 3 shows the potential difference in experiment 4. Measurements were taken immediately before and after soil solution sampling, to investigate any disturbance.

The potential drop between working electrodes was very low (less than 6V). In previous experiments where an insulting material (stone) was placed in the soil during EDR it was seen that the stone did not markedly influence the overall resistivity of the cell (Ottosen et al., 2002), so it is expected that the same counts for the cup. The cup was empty between sampling, and thus is non-conductive, causing the electric field lines to be closer together near it. According to Ottosen et al. (2002) this causes a quite high variability in metal concentrations in the soil in this region when the non-conducting piece has a size which is large compared to the diameter of the cell $(5-7 \mathrm{~cm}$ out of $8 \mathrm{~cm})$. The dimensions of the suction cup were however much less and thus significantly fewer disturbances from the electric field must be expected. The interference of the suction cup on the electric field lines are expected limited.

The voltage over the membranes (Figure $3: \mathrm{a}-\mathrm{c}$ ) is the highest, leaving $1.5 \mathrm{~V}$ to be distributed over the soil. Figure 3(d-h) shows the voltage over the slices. In every case the potential are similar. The cup is placed in slice 5 and neither the sampling nor the cup seems to cause major disturbances in the voltage in (f). There are however some disturbances in (g) probably caused by sampling. Thus, sampling times should be kept as short as possible and the extracted volume of soil solution as small as possible, to limit disturbances. Considering electrode placement in the soil and the voltage measurements it is considered that sampling radius is within few $\mathrm{cm}$ on each side of the cup. 

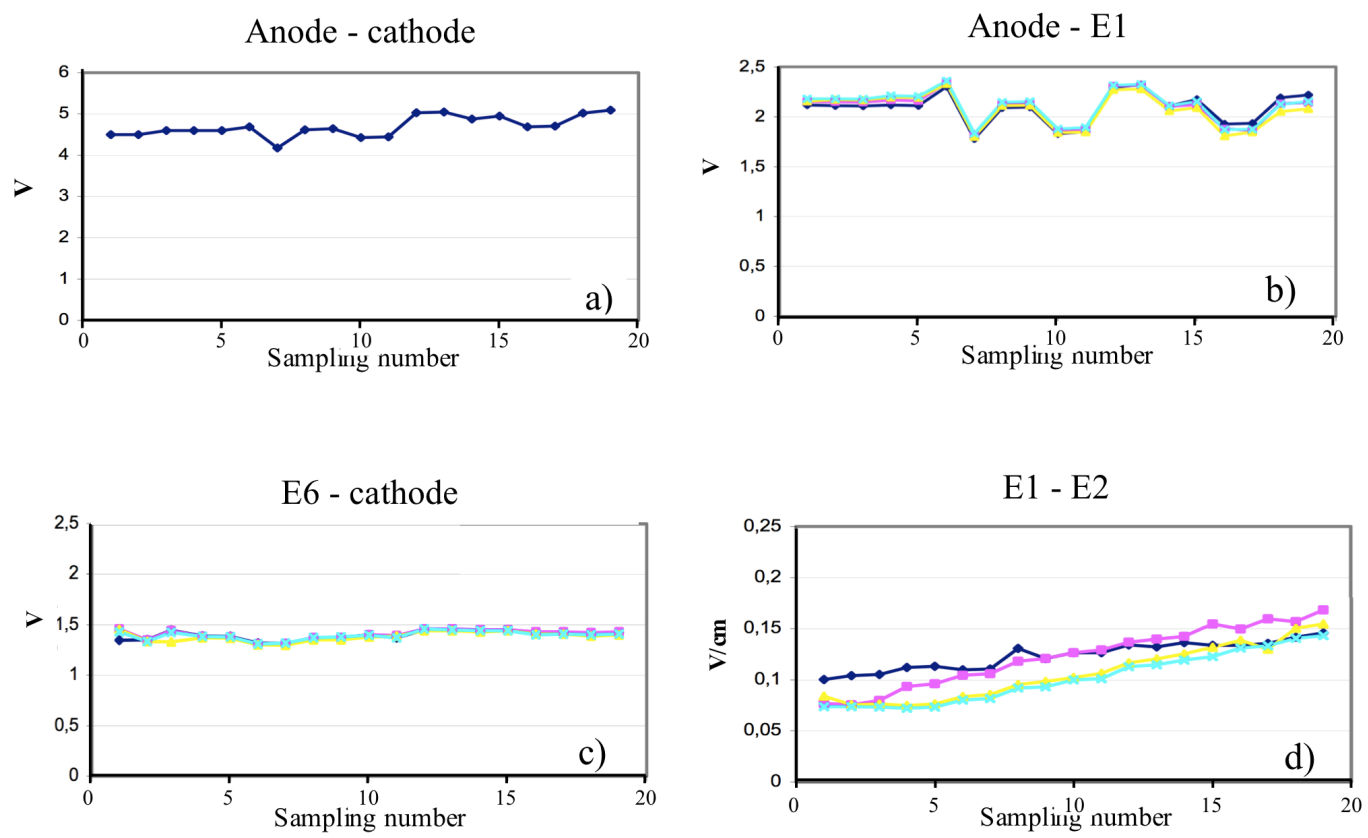

$\mathrm{E} 2-\mathrm{E} 3$

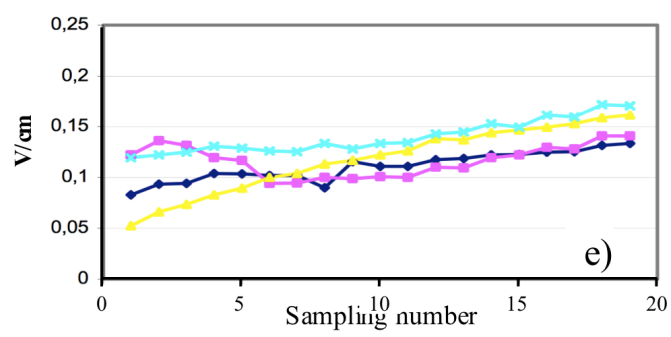

E3 - E4

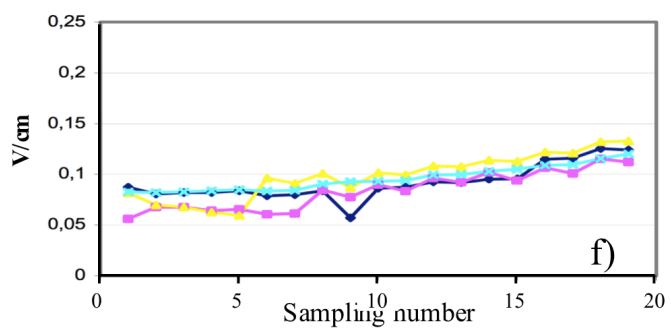

E4 - E5
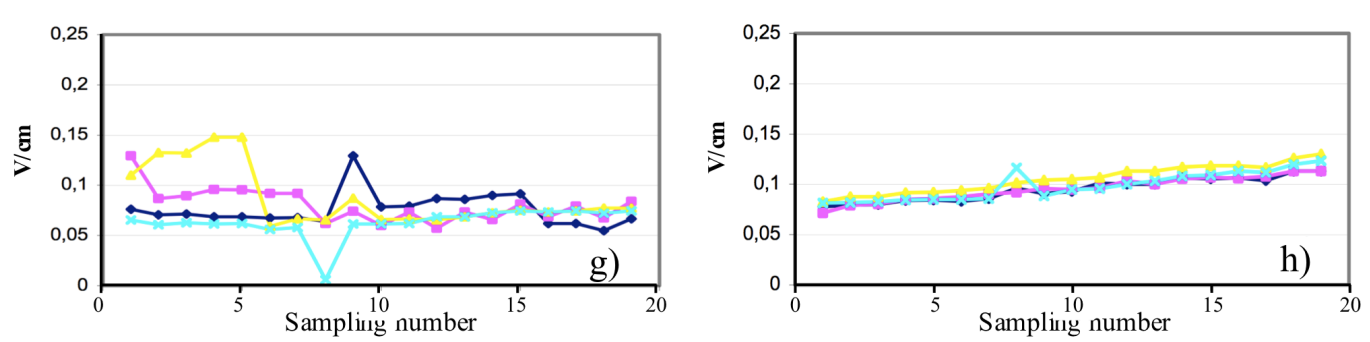

$\longrightarrow$ top

- front

bottom

back

Figure 3: Voltage drop during experiment 4. (a) overall voltage between anode and cathode; (b) voltage drop between anode and E1; (c) Voltage drop between E6 and cathode; (d) Voltage drop between E1 and E2; (e) Voltage drop between E2 and E3; (f) Voltage drop between E3 and E4, including the sampler; (g) Voltage drop between E4 and E5; (h) Voltage drop between E5 and E6. 


\section{Conclusions}

This work describes seven electrodyalytic experiments where ammonium citrate was used as desorbing agent. It was found that $1 \mathrm{M} \mathrm{Am-Cit} \mathrm{gave} \mathrm{higher} \mathrm{levels} \mathrm{of} \mathrm{both} \mathrm{copper} \mathrm{and}$ chromium in soil solution than lower concentrations. Increasing current density from $1.0 \mathrm{~mA}$ $\mathrm{cm}^{-2}$ to $1.5 \mathrm{~mA} \mathrm{~cm}^{-2}$ did not increase the removal of $\mathrm{Cu}$ and $\mathrm{Cr}$, but increasing duration on the other hand did. This reveals that desorption kinetics is a limiting factor.

Soil solution sampling with a suction cup during EDR was successful, following an adjustment in the experimental set-up to prevent soil dewatering. Knowledge of soil solution concentrations allows insight in metal behavior during remediation for evaluation of how to enhance the remediation (e.g. higher current or longer duration). The sampling radius was suggested to be few cm from the cup and overall cell resistivity was not affected by the presence of the cup. While the electric field is compressed in the soil region closest to the cup, the effect is quite limited and is not found to influence remediation.

Final concentrations in the soil ranged from 220-360 $\mathrm{mg} \mathrm{Cu} \mathrm{kg}^{-1}$ (removals: $78 \%-86 \%$ ) and 440-590 mg Cr kg-1 (removals: $35-51 \%$ ), being within the $500 \mathrm{mg} \mathrm{kg}^{-1}$ limit for a clean soil only for $\mathrm{Cu}$. While an optimization is still required for $\mathrm{Cr}$, the results are encouraging and highlight the potential of EDR to remediate soils which are contaminated with a mixture of heavy metals at a neutral to alkaline $\mathrm{pH}$ by choosing a good enhancement solution.

\section{References:}

Alcántara, M.T., Gómez, J., Pazos, M., Sanromán, M., 2012. Electrokinetic remediation of lead and phenanthrene polluted soils. Geoderma 173-174, 128-133. doi:10.1016/j.geoderma.2011.12.009

Bhattacharya, P., Mukherjee, A.B., Jacks, G., Nordqvist, S., 2002. Metal contamination at a wood preservation site: characterisation and experimental studies on remediation. Sci. Total Environ. 290, 165-80.

Brosky R.T., Pamukcu S., 2013. The Role of DDL Processes During Electrolytic Reduction of $\mathrm{Cu}(\mathrm{II})$ in Low Oxygen Environment. J. Hazard Mater. 262, 878-82. 10.1016/j.jhazmat.2013.09.032

Buchireddy, P.R., Bricka, R.M., Gent, D.B., 2009. Electrokinetic remediation of wood preservative contaminated soil containing copper, chromium, and arsenic. J. Hazard. Mater. 162, 490-7. doi:10.1016/j.jhazmat.2008.05.092

Chang, J.-H., Shi, Y.-H, Tung, C.-H., 2010. Stepwise addition of chemical reagents for enhancing electrokinetic removal of $\mathrm{Cu}$ from real site contaminated soils. J. Appl. Electrochem. 40, 1153-1160. doi:10.1007/s10800-010-0083-0 
Chen, J.-L., Yang, S.-F., Wu, C.-C., Ton, S., 2011. Effect of ammonia as a complexing agent on electrokinetic remediation of copper-contaminated soil. Sep. Purif. Technol. 79, 157163. doi:10.1016/j.seppur.2011.02.029

Fan, G., Cang, L., Fang, G., Zhou, D., 2014. Surfactant and oxidant enhanced electrokinetic remediation of a PCBs polluted soil. Sep. Purif. Technol. 123, 106-113. doi:10.1016/j.seppur.2013.12.035

Ferreira, C., Ribeiro, A., Ottosen, L., 2002. Study of different assisting agents for the removal of heavy metals from MSW fly ashes, in: Almorza, D., Brebbia, C., Sales, D., Popov, V. (Eds.), Waste Management and the Environment. WIT Press, Southampton, 171-179.

Ferreira, C.D., Jensen, P., Ottosen, L., Ribeiro, A., 2008. Preliminary treatment of MSW fly ash as a way of improving electrodialytic remediation. J. Environ. Sci. Health. A. Tox. Hazard. Subst. Environ. Eng. 43, 837-843. doi:10.1080/10934520801974319

Gent, D.B., Bricka, R.M., Alshawabkeh, A.N., Larson, S.L., Fabian, G., Granade, S., 2004. Bench- and field-scale evaluation of chromium and cadmium extraction by electrokinetics. J. Hazard. Mater. 110, 53-62. doi:10.1016/j.jhazmat.2004.02.036

Grossmann, J., Udluft, P., 1991. The extraction of soil water by the suction-cup method: a review. J. Soil Science 42, 83-93. doi:10.1111/j.1365-2389.1991.tb00093.x

Hansen, H.K., Ribeiro, A.B., Mateus, E.P., Ottosen, L.M., 2007. Diagnostic analysis of electrodialysis in mine tailing materials. Electrochim. Acta 52, 3406-3411. doi:10.1016/j.electacta.2006.05.066

Jensen, P.E., Ferreira, C.M.D., Hansen, H.K., Rype, J.-U., Ottosen, L.M., Villumsen, A., 2010. Electroremediation of air pollution control residues in a continuous reactor. J. Appl. Electrochem. 40, 1173-1181. doi:10.1007/s10800-010-0090-1

Jensen, P.E., Ottosen, L.M., Allard, B., 2012. Electrodialytic versus acid extraction of heavy metals from soil washing residue. Electrochim. Acta 86, 115-123. doi:10.1016/j.electacta.2012.07.002

Kirkelund, G.M., Jensen, P.E., Villumsen, A., Ottosen, L.M., 2010. Test of electrodialytic upgrading of MSWI APC residue in pilot scale: focus on reduced metal and salt leaching. J. Appl. Electrochem. 40, 1049-1060. doi:10.1007/s10800-009-0059-0

Kirkelund, G.M., Ottosen, L.M., Villumsen, A., 2009. Electrodialytic remediation of harbour sediment in suspension-evaluation of effects induced by changes in stirring velocity and current density on heavy metal removal and $\mathrm{pH}$. J. Hazard. Mater. 169, 685-90. doi:10.1016/j.jhazmat.2009.03.149 
Landrota, G., Tapperob, R., Webb, S.M., Sparks, D.L., 2012. Arsenic and chromium speciation in an urban contaminated soil. Chemosphere, 88 1196-1201. doi:10.1016/j.chemosphere.2012.03.069

Li, T., Guo, S., Wu, B., Li, F., Niu, Z., 2010. Effect of electric intensity on the microbial degradation of petroleum pollutants in soil. J. Environ. Sci. 22, 1381-1386. doi:10.1016/S1001-0742(09)60265-5

Li, C. Lan, Y., Deng, B., 2007. Catalysis of Mn2+ on the reduction of Cr6+ by citrate. Pedosphere, 17, 318-323. doi:10.1016/S1002-0160(07)60038-1

Loeppert, R.H., Suarez D.L. (1995). Methods of Soil Analysis. Part 3. Chemical Methods SSSA Book Series 5, 451-455

Martell A.E. (1977) Critical stability constants. Volume 3: Other organic ligands 161-164

Miljøministeriet (2010). Liste over kvalitetskriterier i relation til forurenet jord og kvalitetskriterier for drikkevand (in Danish) (List of quality criteria for contaminated soil and drinking water)

Nystroem, G.M., Pedersen, A.J., Ottosen, L.M., Villumsen, A., 2006. The use of desorbing agents in electrodialytic remediation of harbour sediment. Sci. Total Environ. 357, 2537. doi:10.1016/j.scitotenv.2005.04.040

Ottosen, L.M., Hansen, H.K., Laursen, S., Villumsen, A., 1997. Electrodialytic Remediation of Soil Polluted with Copper from Wood Preservation Industry. Environ. Sci. Technol. 31, 1711-1715. doi:10.1021/es9605883

Ottosen, L.M., Hansen, H.K., Villumsen, A., Bech-Nielsen, G., 2000. Electrodialytic Remediation of an Arsenic and Copper Polluted Soil. Continous Addition of Ammonia During the Process. Environ. Technol. 21, 1421-1428.

Ottosen, L.M., Eriksson, T., Hansen, H.K., Ribeiro, A.B., 2002. Effects from different types of construction refuse in the soil on electrodialytic remediation. J. Hazard. Mater. B91, 205-219. doi:10.1016/S0304-3894(01)00388-0

Ottosen, L.M., Pedersen, A.J., Ribeiro, A.B., Hansen, H.K., 2005a. Case study on the strategy and application of enhancement solutions to improve remediation of soils contaminated with $\mathrm{Cu}, \mathrm{Pb}$ and $\mathrm{Zn}$ by means of electrodialysis. Eng. Geol. 77, 317-329. doi:10.1016/j.enggeo.2004.07.021

Ottosen, L.M., Cristensen, I. V, Pedersen, A.J., Villumsen, A., 2005b. Electrodialytic Remediation of Heavy Metal Polluted Soil. Lichtfouse, E., Schwarz. J., Robert, D. (Eds.), Environ. Chem. Green Chem. Pollut. Ecosyst. Springer 223-233. 
Ottosen, L.M.; Lepkova, K.; Kubal, M., 2006. Comparison of electrodialytic removal of Cu from spiked kaolinite, spiked soil and industrially polluted soil. J. Hazard. Mater. 137, 113-120. doi:10.1016/j.jhazmat.2005.04.044

Ottosen, L.M., Hansen, H.K., Jensen, P.E., 2009. Electrokinetic removal of heavy metals, in: Electrochemical Remediation Technologies for Polluted Soils, Sediments and Groundwater. Eds. K. Reddy and C. Cameselle, 95-126, John Wiley\&Sons, USA.

Ottosen, L.M., Jensen, P.E., Kirkelund, G.M., Dias-Ferreira, C., Hansen, H.K., 2012. Electrodialytic Remediation of heavy Metal polluted Soil - treatment of water saturated or suspended soil. Chem. Eng. Trans. 28, 103-108. doi:10.3303/CET1228018

Pamukcu S., Weeks A., Wittle J.K., 2004. Enhanced Reduction of Cr (VI) by Direct Electric Current in a Contaminated Clay. Environ. Sci. Technol. 38(4), 1236-1241. doi: http://dx.doi.org/10.1021/es034578v

Pedersen, A.J., 2002. Evaluation of assisting agents for electrodialytic removal of $\mathrm{Cd}, \mathrm{Pb}, \mathrm{Zn}$, $\mathrm{Cu}$ and $\mathrm{Cr}$ from MSWI fly ash. J. Hazard. Mater. 95, 185-198.

Reddy, K.R., Chintamreddy, S., 2004. Enhanced electrokinetic remediation of heavy metals in glacial till soils using different electrolyte solutions. J. Environ. Eng. J130, 442-455.

Ribeiro, A.B., 1998. Use of electrodialytic remediation technique for removal of selected heavy metals and metalloids from soils. Ph. D thesis. Technical University of Denmark, Universidade Nova de Lisboa, Portugal and Estação Agronónomica, Portugal)

Suzuki, T., Niinae, M., Koga, T., Akita, T., Ohta, M., Choso, T., 2014. EDDS-enhanced electrokinetic remediation of heavy metal-contaminated clay soils under neutral $\mathrm{pH}$ conditions. Colloids Surfaces A Physicochem. Eng. Asp. 440, 145-150. doi:10.1016/j.colsurfa.2012.09.050 